\title{
Underwater turning movement during foraging in Hydromedusa maximiliani (Testudines, Chelidae) from southeastern Brazil
}

\author{
Rocha-Barbosa, O. ${ }^{a *}$, Hohl, LSL. ${ }^{a}$, Novelli, IA. ${ }^{b, c}$, Sousa, BM. ${ }^{b}$, \\ Gomides, SC. ${ }^{b}$ and Loguercio, MFC. ${ }^{a}$ \\ ${ }^{\text {a}}$ LAZOVERTE - Laboratório de Zoologia de Vertebrados - Tetrapoda, Departamento de Zoologia, Instituto de Biologia \\ Roberto Alcantara Gomes - IBRAG, Universidade do Estado do Rio de Janeiro - UERJ, Rua São Francisco Xavier, \\ 524, Maracanã, CEP 20550-013, Rio de Janeiro, RJ, Brazil \\ bLaboratório de Herpetologia, Departamento de Zoologia, Instituto de Ciências Biológicas, Universidade Federal de Juiz \\ de Fora - UFJF, Rua José Lourenço Kelmer, s/n, Campus Universitário, São Pedro, \\ CEP 36036-900, Juiz de Fora, MG, Brazil \\ 'Programa de Pós-graduação em Ciências Biológicas, Comportamento e Biologia Animal, Instituto de Ciências Biológicas, \\ Universidade Federal de Juiz de Fora - UFJF, Rua José Lourenço Kelmer, Martelos, \\ CEP 36036-330, Juiz de Fora, MG, Brazil \\ *e-mail: obarbosa@uerj.br
}

Received: April 23, 2013 - Accepted: August 13, 2013 - Distributed: December 31, 2014

(With 4 figures)

\begin{abstract}
A type of locomotor behavior observed in animals with rigid bodies, that can be found in many animals with exoskeletons, shells, or other forms of body armor, to change direction, is the turning behavior. Aquatic floated-turning behavior among rigid bodies animals have been studied in whirligig beetles, boxfish, and more recently in freshwater turtle, Chrysemys picta. In the laboratory we observed a different kind of turning movement that consists in an underwater turning movement during foraging, wherein the animal pivoted its body, using one of the hindlimbs as the fixed-point support in the substratum. We describe, analyze and quantify this movement during foraging in Hydromedusa maximiliani, using observations made in the laboratory. We studied 3 adult specimens ( 2 males, 1 female) and 2 non-sexed juveniles of H. maximiliani. They were kept individually in an aquarium filled with water and small fish. They were filmed, in dorsal view, at 30 frames per second. Sequences were analyzed frame by frame and points were marked on limbs and shell to enable analysis of variation in limb flexion and extension, as well as rotation movements. While foraging, turtles frequently turned their bodies, using one hind leg as the pivot point. This underwater turning movement, in addition to slow movements with the neck stretched, or staying nearly immobile and scanning the surroundings with lateral movements of the neck (in arcs up to $180^{\circ}$ ), and fast attacks of neck, may increase prey capture rates.
\end{abstract}

Keywords: underwater, turning, Hydromedusa maximiliani, fixed point.

\section{Movimento de giro subaquático durante o forrageio em Hydromedusa maximiliani (Testudines, Chelidae) do Sudeste do Brasil}

\begin{abstract}
Resumo
Um tipo de comportamento locomotor observado em animais com corpo rígido, que pode ser encontrado em muitos animais com exoesqueleto, conchas, ou outras formas de armaduras, para mudar de direção, é o girar o corpo num plano horizontal (Turning performance). O movimento de girar o corpo flutuando na água (Aquatic floated-turning performance) entre animais de corpo rígido tem sido estudado em besouros, peixe-caixa, e mais recente na tartaruga de água doce, Chrysemys picta. No laboratório nós observamos um tipo diferente de giro que consiste em um giro subaquático, não flutuando na água, durante o forrageio, onde o animal pivota seu corpo, usando uma das patas traseiras como um ponto fixo de suporte no substrato. Nós descrevemos, analisamos e quantificamos esse movimento durante o forrageio de Hydromedusa maximiliani, usando observações feitas em laboratório. Nós analisamos três adultos ( 2 machos, 1 fêmea) e dois juvenis não sexados. Eles foram mantidos individualmente em um aquário preenchido água e pequenos peixes. Eles foram filmados, em vista dorsal, a 30 imagens por segundo. As sequencias foram analisadas quadro a quadro, e pontos foram marcados nos membros e no casco para permitir analisar variações angulares durante a flexão e extensão, bem como movimentos de rotação. Os membros fizeram movimentos sequencias durante o movimento de giro, mantendo sempre um dos membros posteriores como ponto fixo. Esta estratégia de forrageio associada com movimentos lentos e pescoço esticado, ou permanecer praticamente imóveis apenas observando o ambiente através de movimentos laterais do pescoço, descrevendo trajetórias em um ângulo de $180^{\circ}$, e ataques rápidos com o pescoço, talvez aumente seu potencial na captura de presas.
\end{abstract}

Palavras-chave: subaquático, giro, Hydromedusa maximiliani, ponto fixo. 


\section{Introduction}

Turtles possess one of the most distinctive body plans among vertebrates (Burke, 1989). The presence of a bony shell affords them physical protection from a wide range of predators and environmental hazards, leading to distinctive life histories and survival strategies (Cagle, 1950; Jayes and Alexander, 1980; Gibbons, 1990; Ultsch, 2006). However, the carapace also places unusual constraints on the locomotor ability of turtles, because the carapace bones are fused to the dorsal vertebrae, designing a rigid body plan, which makes their body axis inflexible (Zangerl, 1969; Ernst et al., 1994; Blob et al., 2008). As a consequence, locomotor capacities of turtles completely rely on the movements of their limbs (Gillis and Blob, 2001; Pace et al., 2001; Rivera et al., 2006).

Hydromedusa maximiliani (Testudines, Chelidae) occurs in southeastern and part of northeastern Brazil, endemic to the Atlantic forest biome (Moreira, 1994).

In general, chelonian behavior patterns employ the senses of sound, sight, smell and tactile information during foraging (Belkin and Gans, 1968; Hulse, 1974; Plummer and Farrar, 1981; Molina et al., 1998). Associated specific behavioral patterns and morphological adaptations (Chessman, 1983), such as cryptic color body, and/or fast attacks using the neck in prey capture, make them able to capture elusive prey. This compensates for the apparent disadvantage in locomotor restriction due to the rigid shell (Souza, 1995).

Animals that live in complex habitats or engage in predator-prey interactions may need to change direction frequently as they negotiate obstacles or attempt to evade predators or capture food (Rivera et al., 2006). So, a type of locomotor behavior observed in animals with rigid bodies, that can be found in many animals with exoskeletons, shells, or other forms of body armor (Walker, 2000; Fish and Nicastro, 2003), to change direction, is the turning behavior (Fish and Nicastro, 2003; Rivera et al., 2006). Turning performance is considered by several authors as a critical aspect of locomotion for many animals (Howland, 1974; Gerstner, 1999; Domenici, 2001; Hedenström and Rosén, 2001).

Aquatic floated-turning performance among rigid bodies animals have been studied in whirligig beetles (Fish and Nicastro, 2003), boxfish (Walker, 2000), and more recently in a freshwater turtle, Chrysemys picta (Testudines, Emydidae) (Rivera et al., 2006). This turning is made while they are floating in the water surface.

This particular behavior incorporates two types of motion: (1) rotation around a vertical axis through the center of an organism (reorientation), and (2) translation of this axis (i.e. the center of rotation) across a horizontal plane (Howland, 1974; Norberg and Rayner, 1987; Webb, 1994).

We observed a different kind of turning movement in the laboratory, that consists of an underwater turning movement during foraging, wherein the animal pivoted its body, using one of the hindlimbs as the fixed-point support (vertical axis). We suspect that $H$. maximiliani uses this strategy to capture prey on the bottom of rivers. To test this hypothesis, we describe, analyze and quantify this movement during foraging in $H$. maximiliani, using observations made in the laboratory.

\section{Material and Methods}

Five specimens of $H$. maximiliani were captured for study in the Reserva Biológica Municipal Santa Cândida (RBMSC) (2141'20”'S and 4320'40”W datum), municipality of Juiz de Fora, Minas Gerais, Brazil (2 adult males, 1 adult female and 2 non-sexed juveniles). To study kinematic patterns of turtles during foraging, we used a glass aquarium $(110 \times 39 \times 40 \mathrm{~cm}$ deep) filled with 64 liters of water, with no rocks or sand on the bottom, and with small fishes. Behavior of each turtle was recorded for a total of eight hours, in dorsal and lateral view, by a camera (Panasonic Palmcorder Iq) that filmed 30 frames per second in (i.e., 0.033 seconds between frames). The segments of the recording that contained underwater turning movements $(\mathrm{N}=5)$ were edited with the software First Video Converter 6.0.1 (obtained from www.download. cnet.com) to analyze frame by frame. The best sequences were chosen to analyze, and included turning movements to the left and to the right in dorsal and lateral views. For accurate quantification, angular data were used to represent graphically the extension and flexion of the limbs.

To check the displacement of the limbs, each image was analyzed by marking an anatomical point in each of the four members, always located in the claw of the second toe, another point in the central part of the carapace and a straight medial line going through this central point. Lines were drawn connecting the point of each member to the central point. With this selection, the angles A, B, C and $\mathrm{D}$ (relative to the carapace midline) could be identified (see Figure 1).

During underwater turning movement, the angular changes in the forelimbs were different from those of the hindlimbs. To describe this, we will follow the terminology used by Fish and Nicastro (2003) and Rivera et al. (2006), and assume "inboard" to describe the side of the turtle facing toward the center of the turn, and "outboard" to refer to the side facing away from the center of the turn (Rivera et al., 2006). For the inboard forelimb, high angles mean limb extension, and low angles, flexion (see Figure 2A). On the opposite, for the outboard forelimb, the high angles mean limb flexion, and low angles, extension (see Figure 2B). The same does not occur to the hindlimbs, because the moving hindlimb always will stay in the outboard. High angles mean limb flexion and low angles, extension (see Figure 2C).

\section{Results}

During the observations of foraging behavior of $H$. maximiliani, specimens walked over the substrate with slow movements and the neck stretched, or were practically immovable just looking at the surroundings through lateral movements of the neck of up to $180^{\circ}$. 
On underwater turning movement, the turtle pivoted its body, using the inboard hindlimb as a fixed pivot point. These turns are made with the limbs being used sequentially, always the two forelimbs and one of the hindlimbs. For example, in a turn starting of a static position (see Figure 3A), first, the outboard forelimb, flexed, leaves the ground (swing phase) and extends laterally, in a cranial direction. When it hits the ground (stance phase), the outboard hindlimb extends backward and the inboard forelimb flexes backward, both exerting force against the ground and impelling the body to the turning movement (see Figure 3B).

Next, the outboard forelimb is flexed backwards (caudal direction) toward the outboard hindlimb. At this stage, it exerts the necessary force to continue the turning movement of the animal body. At the same time the outboard hindlimb leaves the ground extended, flexes forward and hits the ground, and the inboard forelimb, flexed, leaves the ground, extends laterally and hits the ground (see Figure 3C). These turning stages produce

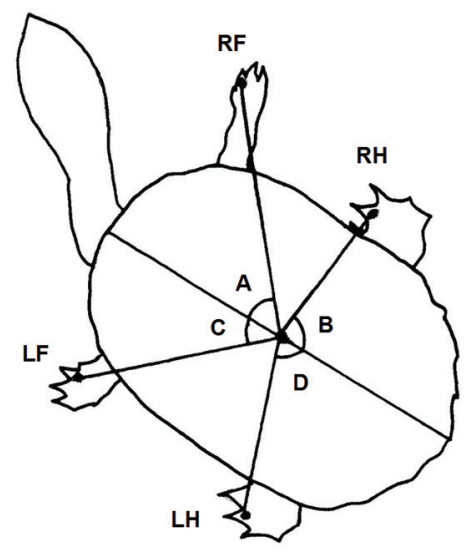

Figure 1. Schematic view of the method used to analyze the flexion and extension of the limbs. Variations on the angles A, B, C and D are used to identify flexions and extensions. Legends: LF $=$ Left Forelimb; RF = Right Forelimb; LH = Left Hindlimb; RH = Right Hindlimb. a sequential limb cycle which repeats itself during the underwater turning movement (see Figure 3D). Figure 4 shows these quantified movements by angular variation and representing it graphically.

\section{Discussion}

The foraging behavior observed for $H$. maximiliani was in agreement with the preliminary descriptions by Souza and Abe (1995), Chagas and Raposo-Filho (1999), and Souza (2004a, b), except for the addition of an underwater turning movement, that was only observed on this work. However, those previous studies were made in the field, making it impossible to note more detailed behaviors, like those of Molina (1990) for other species of Brazilian Chelidae, (e.g., Phrynops geofroanus and Hydromedusa tectifera) observed in captivity.

Previous studies of the behavior of $H$. maximiliani have emphasized reproductive behavior (Chagas and RaposoFilho, 1999; Novelli and Sousa, 2007), feeding behavior (Chagas and Raposo-Filho, 1999; Novelli and Sousa, 2006), and more recently, "grooming behavior" (Novelli et al., 2009). These studies didn't focus on kinematic patterns during foraging.

The kinematic pattern used by freshwater turtles during foraging was well studied by Rivera et al. (2006), describing limb kinematics and performance of aquatic body turning executed by $C$. picta. Here we observed another kind of turning movement, named on this paper as underwater turning movement, presented by $H$. maximiliani.

When Rivera et al. (2006) studied the movement of limbs during forward aquatic turning in the freshwater painted turtle, C. picta, they compared it with limbs movements of rectilinear swimming.

They observed that in forward turns, turtles executed turns by alternating movements of the hindlimbs, similar to the pattern of hindlimb movement employed during rectilinear swimming. However, during rectilinear swimming, synchronous movements of contralateral fore- and hindlimbs appear to help maintain a straight trajectory. In forward turns, the pattern of forelimb motions is modified. During forward turns, the inboard forearm is held in a protracted

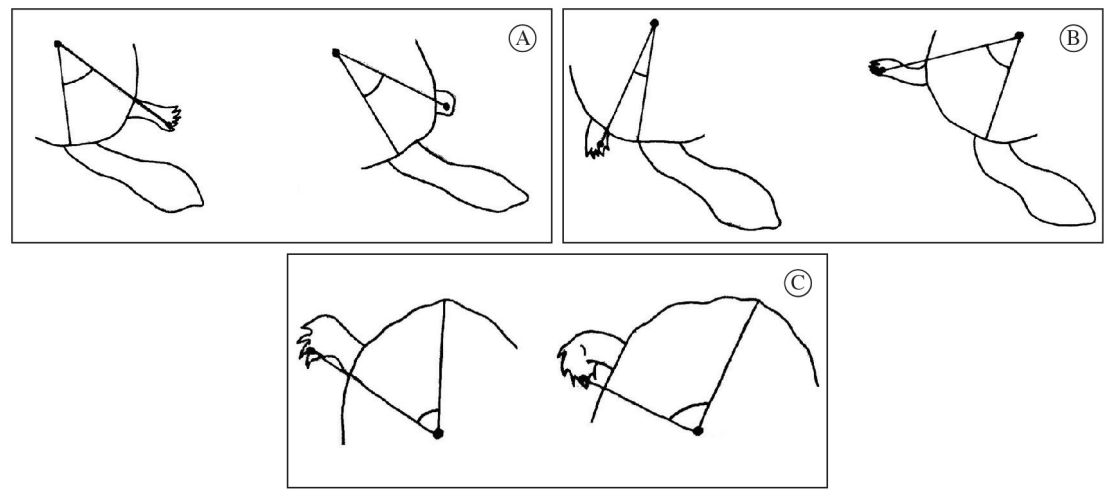

Figure 2. Analysis of the angles on underwater turning movement. (A) Extension and flexion of the inboard frontlimb. (B) Extension and flexion of the outboard frontlimb. (C) Extension and flexion of the outboard hindlimb. 

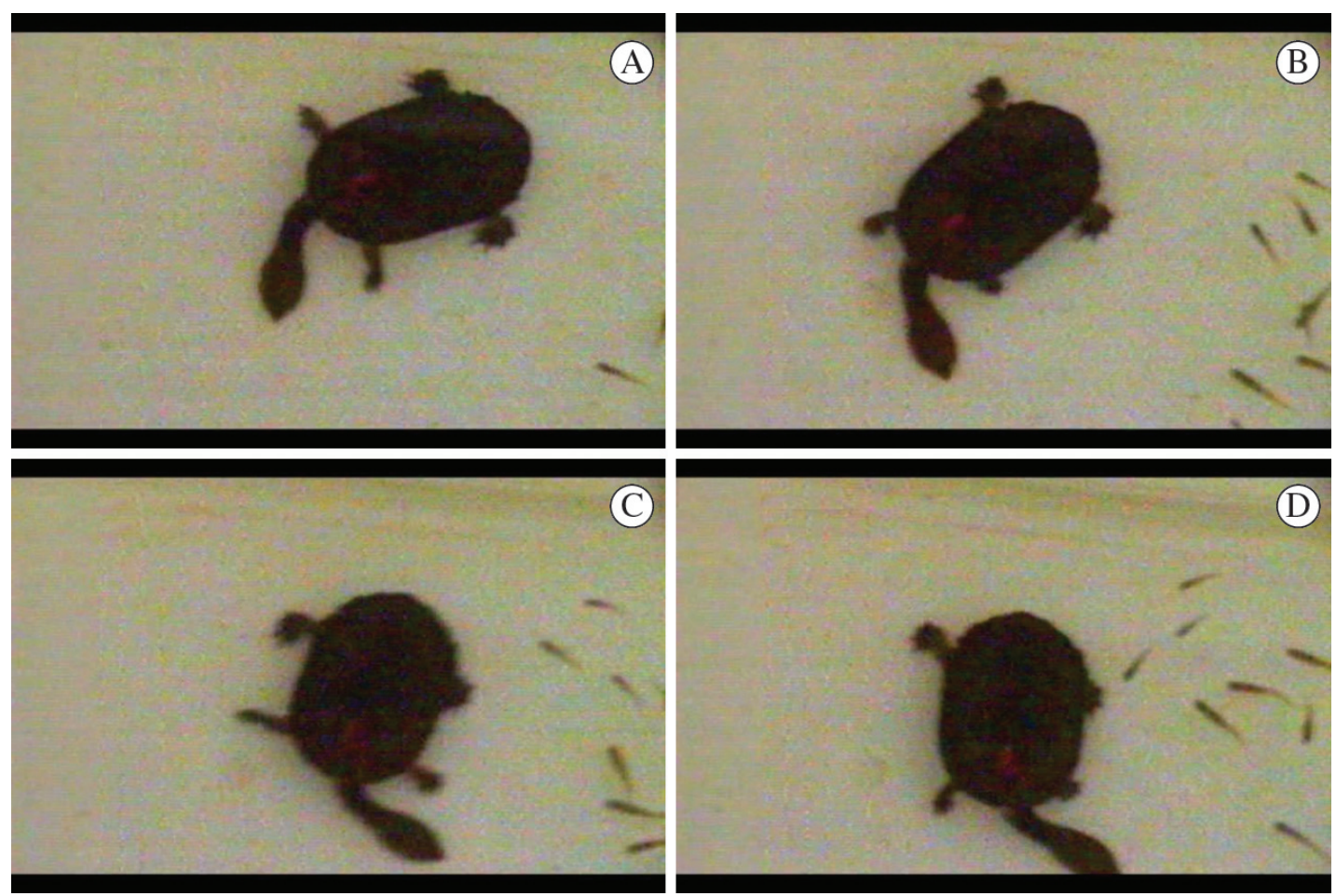

Figure 3. Sequential cycle of the rotation movement during a left turn, pivoting on the LH (left hindlimb). The static position is represented in A; the extension of RF (right forelimb) and RH (right hindlimb), and flexion of LF (left forelimb) is represented in $\mathrm{B}$; the flexion of $\mathrm{RF}$ and $\mathrm{RH}$, and extension of $\mathrm{LF}$ is represented in $\mathrm{C}$; in $\mathrm{D}$ there is the same moment of $\mathrm{B}$, starting a new cycle.

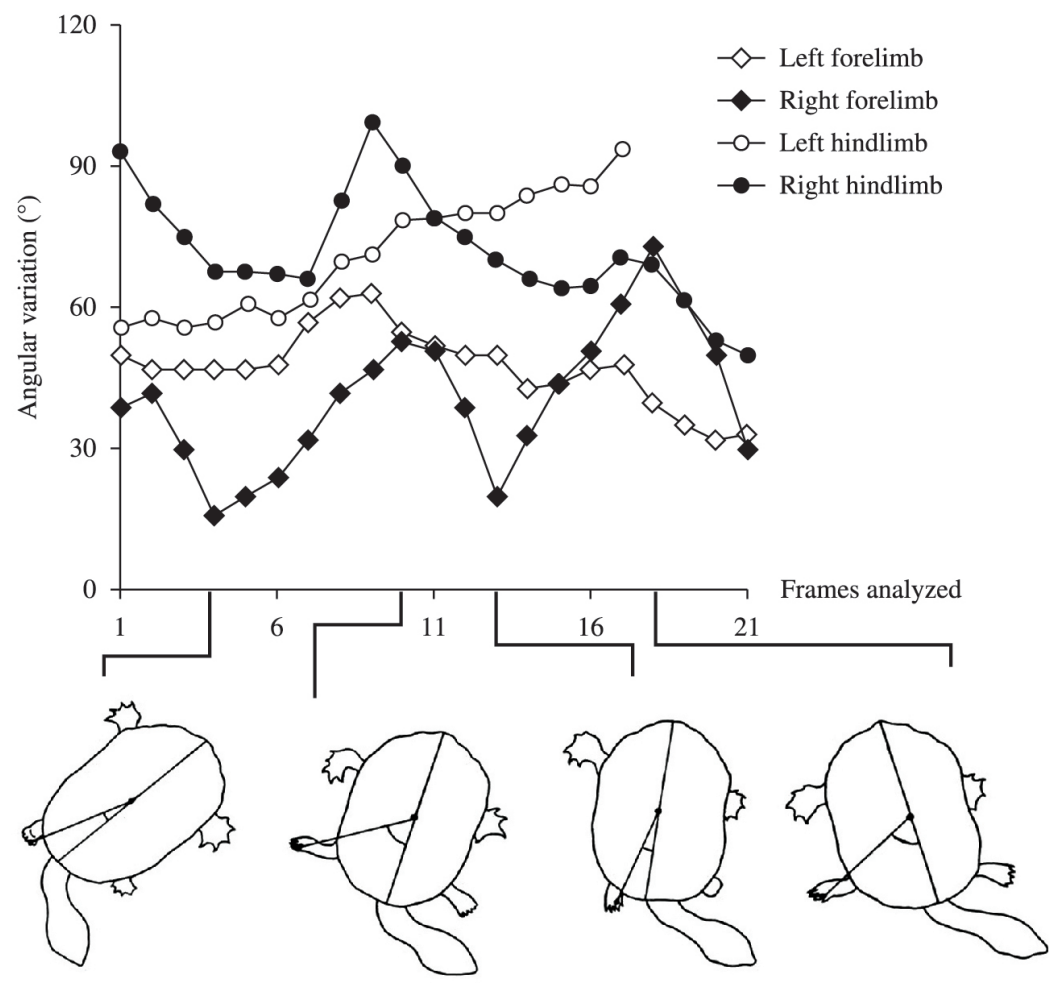

Figure 4. Angular variation $\left(^{\circ}\right)$ of each limb during H. maximiliani' underwater turning movement. The schemes represent the position of each limb in a determined frame during locomotor cycles steps. 
position throughout the turn; this should increase drag on the inboard side, allowing the forelimb to function as a pivot (Fish and Nicastro, 2003). The outboard forelimb continues to move as in rectilinear swimming, producing torque (i.e. a turning moment) about the inboard pivot and effecting the turn. The outboard forelimb moves in alternation with the ipsilateral hindlimb and synchronously with the contralateral hindlimb (i.e. maintains the pattern of movement seen in rectilinear swimming) (Rivera et al., 2006).

The locomotor behavior of Chrysemys picta marginata (Testudines, Emydidae) studied by Walker (1971) showed the locomotor cycle during terrestrial movement in a straight line. We observed that the locomotor cycle of $H$. maximiliani during underwater turning is similar to the one described for C. p. marginata on straight line terrestrial movement.

During underwater turning the inboard hindlimb is used as a fixed pivot point, and the other limbs are used to produce a turning movement, following the stride stages for a straight line movement described by Walker (1971). The difference of stride stages is in relation to "direction" of extended movement of forelimbs. To have a turning movement, inboard and outboard forelimbs have to be extended laterally in relation to the body axis and the inboard hindlimb have to be used as a fixed pivot point. While to have a straight line, forelimbs have to be extended forward in relation to the body axis.

As described by Souza (1995), we also observed that, during forage rotation, the animals examined the substrate using the neck in a $180^{\circ}$ arc. According to Molina (1990), wild adult and sub-adult behavior changes very little when they are kept in good captive conditions, which implies a similar foraging behavior for wild and captive animals.

Hydromedusa maximiliani seems to use a specific turning strategy to capture prey under captive conditions and perhaps also at the bottom of rivers. This strategy in addition to walking over the substrate with slow movements and the neck out-stretched, or staying practically immobile while scanning the surroundings through lateral movements of the neck (up to $180^{\circ}$ ), and fast attacks of neck, may increase the potential for prey capture in this species, since they are exclusively carnivorous animals.

The turtle carapace places unusual constraints on its locomotor system, as the carapace bones are fused to the dorsal vertebrae, making the body axis inflexible. Turning movements during foraging both floating and underwater in contact with the substrate seem an interesting solution to finding and capturing prey for organisms with this Bauplan. Agility and maneuverability (Rivera et al., 2006) are very important for turning movements.

Rigid-body animals that have been examined to date have excelled in one of these two parameters, but not both (Rivera et al., 2006). Boxfish are highly maneuverable, but have low agility (Walker, 2000); whirligig beetles can rotate with high agility, but are not very maneuverable (Fish and Nicastro, 2003); freshwater painted turtles display intermediate values for both (Rivera et al., 2006). In the present study, we did not analyze these two parameters for underwater turning movement, restricting our results to descriptive analyses, as we had a limited sample. Therefore, further investigations addressing these parameters to the underwater turning movements are necessary to better compare results with these others studies.

\section{Acknowledgments}

The authors would like to thank Dr. J. B. Iverson, scientist affiliated with Society for the Study of Amphibians and Reptiles, for English review. CETREINA/UERJ, Prociência Program/UERJ, FAPERJ (L.S.L.Hohl: E-26/101.059/2007; J.D. Barros-Filhos: E-26/100.235/2008) and CNPq (O.RochaBarbosa: 312942/2009-5; M.F.C.Loguercio: 150651/20104) for financial support. This study was approved by the Ethics Commission for Animal Experimentation (Comissão de Ética na Experimentação Animal, COBEA) of Pro-Rectory of Research/UFJF, in an assembly on 12 April 2005 (Protocol number 011/2005-CEA) and under the IBAMA license $075 / 2004-N U F A S / M G$ and process 02015.003546/04-11.

\section{References}

BELKIN, AC. and GANS, C., 1968. An unusual chelonian feeding niche. Ecology, vol. 49, no. 4, p. 768-769. http://dx.doi. org/10.2307/1935544.

BLOB, RW., RIVERA, ARV. and WESTNEAT, MW., 2008. Hindlimb function in turtle locomotion: Limb movements and muscular activation across taxa, environment, and ontogeny. In WYNEKEN, J., GODFREY, M.H. and BELS, V. (Eds.). Biology of Turtles. Boca Raton: CRC Press. p. 139-159.

BURKE, AC., 1989. Epithelial-mesenchymal interactions in the development of the Chelonian Bauplan. In SPECHTANA, H. and HILGERS, H. (Eds.). Trendsin vertebrate morphology. Stuttgart: Fischer Verlag. p. 206

CAGLE, FR., 1950. The life history of the slider turtle, Pseudemys scripta troosti (Holbrook). Ecological Monographs, vol. 20, no. 1, p. 31-54. http://dx.doi.org/10.2307/1943522.

CHAGAS, ACS. and RAPOSO-FILHO, JR., 1999. Biologia do comportamento de Hydromedusa Maximiliani (Mikan, 1820) (Testudines: Chelidae) na Reserva biológica Santa Cândida em Juiz de Fora - MG. Bioscience Journal, vol. 15, no. 2, p. 15-23.

CHESSMAN, B., 1983. Observations on the diet of the broadshelled turtle, Chelodina expansa Gray (Testudines: Chelidae). Australian Wildlife Research, vol. 10, no. 1, p. 169-172. http:// dx.doi.org/10.1071/WR9830169.

DOMENICI, P., 2001. The scaling of locomotor performance in predator-prey encounters: from fish to killer whales. Comparative Biochemistry and Physiology. Part A, Molecular \& Integrative Physiology, vol. 131, no. 1, p. 169-182. http://dx.doi.org/10.1016/ S1095-6433(01)00465-2. PMid:11733175

ERNST, CH., LOVICH, JE. and BARBOUR, RW., 1994. Turtles of the United States and Canada. Washington: Smithsonian Institution Press.

FISH, FE. and NICASTRO, AJ., 2003. Aquatic turning performance by the whirligig beetle: constraints on maneuverability by a rigid 
biological system. The Journal of Experimental Biology, vol. 206, no. Pt 10, p. 1649-1656. http://dx.doi.org/10.1242/jeb.00305. PMid:12682097

GERSTNER, CL., 1999. Maneuverability of four species of coral-reef fish that differ in body and pectoral-fin morphology. Canadian Journal of Zoology, vol. 77, no. 7, p. 1102-1110. http:// dx.doi.org/10.1139/z99-086.

GIBBONS, JW., 1990. Life history and ecology of the slider turtle. Washington: Smithsonian Institution Press.

GILLIS, GB. and BLOB, RW., 2001. How muscles accommodate movement in different physical environments: aquatic vs. terrestrial locomotion in vertebrates. Comparative Biochemistry and Physiology. Part A, Molecular \& Integrative Physiology, vol. 131, no. 1, p. 61-75. http://dx.doi.org/10.1016/S1095-6433(01)004664. PMid: 11733167

HEDENSTRÖM, A. and ROSÉN, M., 2001. Predator versus prey on aerial hunting and escape strategies in birds. Behavioral Ecology, vol. 12, no. 2, p. 150-156. http://dx.doi.org/10.1093/ beheco/12.2.150.

HOWLAND, HC., 1974. Optimal strategies for predator avoidance: the relative importance of speed and manoeuvrability. Journal of Theoretical Biology, vol. 47, no. 2, p. 333-350. http://dx.doi. org/10.1016/0022-5193(74)90202-1. PMid:4437191

HULSE, AC., 1974. Food habits and feeding behavior in Kinosternon sonoriense (Chelonia: Kinosternidae). Journal of Herpetology, vol. 8, no. 3, p. 195-199. http://dx.doi.org/10.2307/1563164.

JAYES, AS. and ALEXANDER, RM., 1980. The gaits of chelonians: Walking techniques for very slow speeds. Journal of Zoology, vol. 191, no. 3, p. 353-378. http://dx.doi.org/10.1111/j.1469-7998.1980. tb01464.x.

MOLINA, FB., 1990. Observações sobre os hábitos e o comportamento alimentar de Phrynops geoffroanus (Schweigger, 1812) em cativeiro (Reptilia, Testudines, Chelidae). Revista Brasileira de Zoologia, vol. 7, no. 3, p. 319-326. http://dx.doi. org/10.1590/S0101-81751990000300014.

MOLINA, FB., ROCHA, MB. and LULA, LABM., 1998. Comportamento alimentar e dieta de Phrynops hilarii (Duméril \& Bibron) em cativeiro (Reptilia, Testudines, Chelidae). Revista Brasileira de Zoologia, vol. 15, no. 1, p. 73-79.

MOREIRA, GM., 1994. Dados preliminares do projeto de distribuição, status populacional e manejo de quelônios de água doce da Mata Atlântica do Brasil. Chelonia Neotropica, vol. 1, no. 1, p. 9-11.

NORBERG, UML. and RAYNER, JMV., 1987. Ecological morphology and flight in bats (Mammalia; Chiroptera): Wing adaptations, flight performance, foraging strategy and echolocation. Philosophical Transactions of the Royal Society of London Series B: Biological Sciences, vol. 316, no. 1179, p. 335-427. http:// dx.doi.org/10.1098/rstb.1987.0030

NOVELLI, IA. and SOUSA, BMD., 2006. Hábitos alimentares de Hydromedusa maximiliani (Mikan, 1820) (Testudinata, Chelidae) da Reserva Biológica Municipal Santa Cândida, Juiz de Fora, Minas Gerais. Revista Brasileira de Zoociências, vol. 8, no. 2, p. 210.
NOVELLI, IA. and SOUSA, BM., 2007. Análise descritiva do comportamento de corte e cópula de Hydromedusa maximiliani (Mikan, 1820) (Testudines, Chelidae) em laboratório. Revista Brasileira de Zoociências, vol. 9, p. 49-56.

NOVELLI, IA., VIEIRA, FM. and SOUSA, BM., 2009. Hydromedusa maximiliani (Brazilian Snake-necked Turtle) Grooming Behavior. Herpetological Review, vol. 40, p. 435-436.

PACE, CM., BLOB, RW. and WESTNEAT, MW., 2001. Comparative kinematics of the forelimb during swimming in red-eared slider (Trachemys scripta) and spiny softshell (Apalone spinifera) turtles. The Journal of Experimental Biology, vol. 204, no. Pt 19, p. 3261-3271. PMid:11606600

PLUMMER, MV. and FARRAR, DB., 1981. Sexual dietary differences in a population of Trionyx muticus. Journal of Herpetology, vol. 15, no. 2, p. 175-179. http://dx.doi. org/10.2307/1563377.

RIVERA, G., RIVERA, ARV., DOUGHERTY, EE. and BLOB, RW., 2006. Aquatic turning performance of painted turtles (Chrysemys picta) and functional consequences of a rigid body design. The Journal of Experimental Biology, vol. 209, no. Pt 21, p. 4203-4213. http://dx.doi.org/10.1242/jeb.02488. PMid:17050835

SOUZA, FL., 1995. História natural do cágado Hydromedusa maximiliani (Mikan, 1820) no Parque Estadual de Carlos Botelho, SP, região de Mata Atlântica (Reptilia, Testudines, Chelidae). Rio Claro: Universidade Estadual Paulista Júlio de Mesquita Filho. Dissertação de Mestrado.

SOUZA, FL., 2004a. Uma revisão sobre padrão de atividade, reprodução e alimentação de cágados brasileiros (Testudines: Chelidae). Phyllomedusa, vol. 3, no. 1, p. 15-27. http://dx.doi. org/10.11606/issn.2316-9079.v3i1p15-27.

SOUZA, FL., 2004b. Hydromedusa maximiliani: la tortuga brasileña de cuello largo. Reptilia, vol. 53, p. 51-55.

SOUZA, FL. and ABE, AS., 1995. Observations on feeding habitats of Hydromedusa maximiliani (Testudines: Chelidae) in southeastern Brazil. Chelonian Conservation and Biology, vol. 1 , no. 4 , p. $320-322$

ULTSCH, GR., 2006. The ecology of overwintering among turtles: where turtles overwinter and its consequences. Biological Reviews of the Cambridge Philosophical Society, vol. 81, no. 3, p. 339-367. http://dx.doi.org/10.1017/S1464793106007032. PMid:16700968

WALKER, JA., 2000. Does a rigid body limit maneuverability? The Journal of Experimental Biology, vol. 203, no. Pt 22, p. 3391-3396. PMid:11044378.

WALKER JUNIOR, WF., 1971. A structural and functional analysis of walking in the turtle, Chrysemys picta marginata. Journal of Morphology, vol. 134, no. 2, p. 195-214. http://dx.doi. org/10.1002/jmor.1051340205. PMid:5135653

WEBB, PW., 1994. The biology of fish swimming. In MADDOCK, L., BONE, Q. and RAYNER, JV. (Eds.). Mechanics and physiology of animal swimming. Cambridge: Cambridge University Press. p. 45-62.

ZANGERL, R., 1969. The turtle shell. In GANS, C., BELLAIRS, Ad'A. and PARSONS, TS. (Eds.). Biology of the Reptilia. New York: Academic Press. p. 311-339. vol. 1. 